International Journal of Instruction

e-ISSN: 1308-1470 • www.e-iji.net
July $2019 \bullet$ Vol.12, No.3

p-ISSN: 1694-609X

pp. 497-512

Received: 19/11/2018

Revision: 11/04/2019

Accepted: 15/04/2019

OnlineFirst:11/05/2019

\title{
Influence of Test Construction Knowledge, Teaching Material and Attitude on Sociological Subject to Quality of Objective Test in Public and Private Vocational Schools
}

\section{Extris Rivai}

Universitas Negeri Jakarta, Indonesia, extris@yahoo.com

\section{Achmad Ridwan}

Universitas Negeri Jakarta, Indonesia, achmadridwan@unj.ac.id

Yetti Supriyati

Universitas Negeri Jakarta, Indonesia, y_supriyati@yahoo.com

\section{Yuli Rahmawati}

Universitas Negeri Jakarta, Indonesia,yrahmawati@unj.ac.id

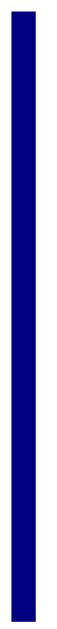
The purpose of the study is to understand the influence on the construction knowledge test, mastery of teaching materials and attitude Sociological Subject to the quality of an objective test developed by vocational school teachers in Indonesia. This quantitative approach with survey methods was used to undertake the research. Data were analyzed by using regression techniques to test the hypothesis. The study involved 65 of Sociology teachers in Public and Private vocational schools. Test and non-test techniques were used to collect the data. The results of this study indicate that (1) test construction knowledge has a positive effect on the quality of objective tests made by the teacher (2) the Sociology teaching materials have a positive effect on the quality of the objective artificial test. (3) Attitudes towards the sociology lesson show a positive influence. (4) Knowledge of test construction has a positive effect on attitude on sociology lesson. (5) Mastery of sociological teaching materials has a positive effect on attitudes towards sociology lesson. Thus, it is expected that all teachers should try to develop their teaching competency in various ways to achieve the results consistent with best practice.

Keywords: objective test quality, teacher knowledge, attitude, Sociology lessons, test construction knowledge 


\section{INTRODUCTION}

Technological developments can not be separated from the development of science, and the place for the development of knowledge is education. The advancement of science and technology is becoming more challenging within the education system. Students are required to develop $21^{\text {st }}$ century skills in facing global challenges within their competences (Tritiyatma, Rahmawati, \& Ridwan, 2017). In this study context, the students in vocational schools are required to have skills and knowledge in facing workforce challenges (Inyiagu, 2014). In addition, UNESCO (2001) stated Technical Vocational Education and Training (TVET) as education process that involves practical skills, attitudes, understanding and knowledge related to workforce. This challenge demands the hard work of various agencies involved in the fields of education, such as government and schools. Education must be able to provide an environment that allows each student to optimally develop their talents, interests, and abilities which include cognitive, affective, psychomotor domains.

Learning as a psychological activity that happens through active interactions with the environment which lead to the transformation of knowledge, skills, and attitudes. It required integrated several factors including assessment and teaching materials. Interaction between teacher and students is the one of fundamental factors in the learning process, where the teacher should facilitate students' engagement through active learning (Rahmawati, 2013). In addition to learning atmosphere and process should enables students to actively develop their potential, to possess spiritual insight, self-control, personality, intelligence, noble character, and skills that needed for the society, nation, state as well as for themselves (Wahyudin, 2018). Quality education in the development of human resources is crucial to face the challenging problems. The problem of improving the quality of education relates to the learning process and assessment such as in preparing teaching materials and constructing test for students.

Evaluation as an important component of the education system should be used to evaluate student learning outcomes. Evaluation of student learning outcomes places emphasis on obtaining information about how many students achieve the learning objectives. Besides, evaluation can be used to determine how successful the teacher has been in the learning process. To find out students' achievement, in this study the test was employed to measure students' understanding. A similar study was conducted by Gichuhi (2011), the test as an assessment technique is a tool used to obtain information on the level of intelligence of students. His findings suggest that training can improve teacher-made tests for effective learning assessment. Rohaan et al. (2012) claim that teacher knowledge on the subject plays an important role in influencing students' understanding. Therefore, it is suggested that a focus on developing knowledge on the subject will affect the level of confidence in teaching positively and can improve student achievement.

Osadebe (2008) observed tests in various subject that construct by the teachers are not good and poorly designed. The students can loose their interest in a particular subject if they get improper evaluation. Teachers should competent in teaching to give the best result consistent with best practice. That are the reasons why this study conducted to 
evaluate the teaching and learning process to understand the effect of test construction knowledge and teaching material and attitude to quality objective test. So the teachers can evaluate the lack of their teaching method, materials, knowledge and attitude toward students. It means that teachers should perform well in evaluating students' assessment information and practices (Ololube, 2008). Understanding the general and fundamental principles and ideas in assessment is the most essential part on enhancing students' learning and teacher effectiveness (McMillan, 2000).

Osadebe (2015) construct test with procedures such as planning, item writing, item analysis, composition of items, test theory, reliability, printing and manual preparation. These procedures use to identify the content area, format and table specification on the test. Darling-Hammond (2000) conclude that the quality of test depends on the quality of the teacher which affected by the level of their competence. There are several criterias for asssesment validation process such as it should align with learning goals and the characteristic of the student (Khalid, 2011).

Based on the observation, the quality of objective tests that made by the Sociology teachers of Public and Private vocational schools in Jakarta influence by teachers' knowledge of test construction, mastery of teaching materials, attitudes toward subject, creativity, preserverance, educational background, motivation, commitment, organizational and management. Besides the factors mentioned above, there are several other problems that can not be separated from the teachers' roles. These problems are as follows: (1) the teachers have not been able to make a test or evaluate students properly, (2) teachers only make a test when it is needed, moreover without thinking about the standard or criteria, (3) the teachers do not attempt proper difficulties to test students, (4) the teacher only knows the terms of evaluation, but does not understand the meaning, purpose and way of doing it well, (5) the teacher does not understand the concept of validity, reliability (6) the teachers seldom arrange questions refer to the guideline but tend to be prepared based on experience and knowledge, (7) questions tend to be arranged before the exam will be carried out (lack of preparation), (8) the teacher only use several books as their references and they use students' worksheet that was not reliable. Test construction knowledge and teaching material attitude are one of the factor that can be a tool to evaluate the teacher and learning process. These tools can measured the learning goals so these should be precise and accurate as what teacher intends to measure and evaluate.

Based on these findings, teachers are advised to guide students by demonstrating positive behavior. Ell et al. (2012) state that a teacher's initial or prior knowledge is very important and can affect or determine the success of the learning process. Students' prior knowledge will enable a teacher to identify key elements of a lesson to focus on before the start of learning. Likewise, Nilsson and Driel (2011) state that there is a strong relationship between teacher attitudes toward subjects and their confidence to teach their subjects which, in turn, will affect students' understanding and attitudes. Minor (2016), shows that high-quality teachers are confident and are better to answer student questions and focus on learning because they are supported by strong knowledge. They are more likely to provide deep and meaningful engagement with the 
subject. In order to assess both the success of students in learning process and the teacher in the teaching, assessment instruments must be used that include instruments made by the teacher which is high quality, reliable, and can be validated.

Therefore, the study focused on influence on the construction knowledge test, mastery of teaching materials and attitude to the quality of an objective test developed by Sociology vocational teachers in Jakarta. The Sociology lessons considered as challenging lesson for engaging students learning in vocational schools as it is not the major subject. However, students are required to learn the subject, especially in developing their social competences in the society. Previous studies are limited to explore different factors, especially assessment. Therefore, these three factors has been studied to explore the factors in learning sociology, especially in constructing test for measuring students' competences. The results of this study are expected to be useful both theoretically and practically. Theoretical uses are to increase knowledge about making quality tests so as to improve the quality of education. The practical uses of this study are as feedback for sociology teachers in improving the quality of assessment and teaching and learning activities on student learning achievement.

This quantitative approach with survey methods was employed with the research questions of:

1. Does the knowledge of test construction directly affect the quality of teachermade objective tests?

2. Does the persuasive communication affect directly the quality of service?

3. Does the attitude on Sociology lessons influence directly the quality of teachermade objective tests?

4. Does knowledge of test construction affect a direct effect on the attitude of Sociology lessons?

5. Does mastery of teaching materials affect directly towards the attitude of Sociology lessons?

\section{METHOD}

The study involved the population of 79 sociology teachers of Public and Private vocational Schools in Jakarta. The sample was determined by random sampling technique with a population of 79 people taken as many as 65 respondents based on the table, at the level of error of 5\%. The research data was collected through tests and questionnaires for each research variable. For the test instrument, each item was arranged using a dichotomy scale and for non-test instruments each item was arranged using a politomic scale, which provide five alternative choices of respondents. The test technique is used to capture data about Exogenous Variables which are Knowledge Construction Tests (X1), and Mastery of Teaching Materials (X2), and non-test techniques or questionnaires used to collect data about Exogeneous variables which is Attitudes Over Sociology Learning (X3). In Addition, Endogenous variables, the Quality of Teacher-Made Objective Tests, denoted by (Y).

Based on the research problems and objectives, the method in conducting the research is the path analysis using structural equations named dimensional causality influences Test 
Construction Knowledge (X1) and Mastery of Teaching Materials (X2) on Attitudes to Sociology Lessons (X3), and causality influence of Test Construction Knowledge (X1), Mastery of Teaching Materials (X2) and Attitudes to Sociology Lessons (X3), to the Quality of Teacher-Made Objective Tests (Y).

The research aims to prove that there is no exogenous variable effect on endogenous variables using a path analysis method, either partially or jointly, and to look at problems and find solutions to improve the quality of objective tests that made by the teacher. Following is the path diagram:

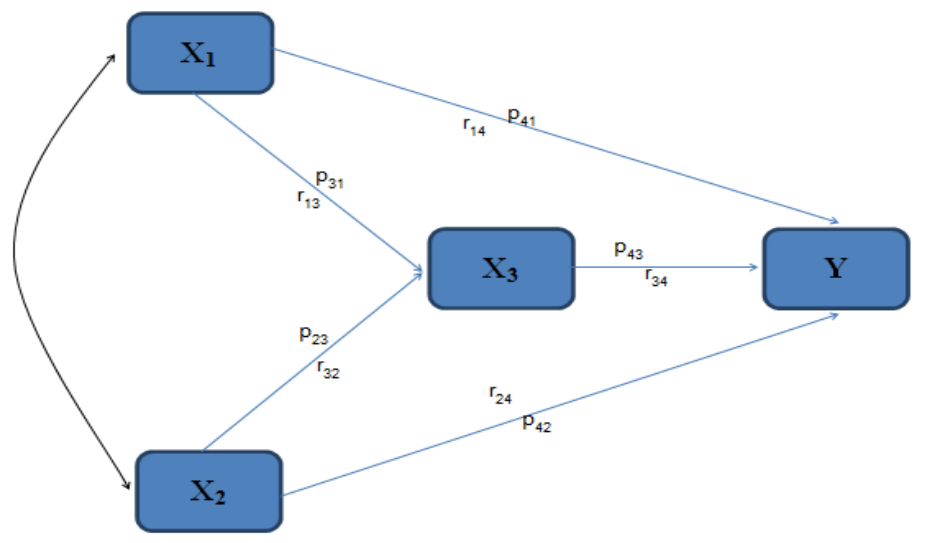

Figure1

The Path Diagram 
Table 1

Validity and Reliability

\begin{tabular}{|c|c|c|c|c|}
\hline & Tes Quality & $\begin{array}{l}\text { Test Construction } \\
\text { Knowledge }\end{array}$ & $\begin{array}{l}\text { Teaching Material } \\
\text { Mastery }\end{array}$ & $\begin{array}{l}\text { Attitude towards } \\
\text { Sociology Subject }\end{array}$ \\
\hline Total Amount & 50 & 45 & 50 & 45 \\
\hline Valid Amount & 50 & 22 & 44 & 41 \\
\hline Validity Test & Content Validity & Biserial Point & Biserial Point & Moment Product \\
\hline Reability Score & KR-20 (0.935) & KR-20 (0.959) & KR-20 (0.970) & Alpha Cronbach (0.946) \\
\hline Dimension & \multicolumn{2}{|c|}{$\begin{array}{l}\text { - Concept and Test } \\
\text { - Ponstruction } \\
\text { - } \quad \text { Further Test Construction }\end{array}$} & $\begin{array}{l}\text { - The function of } \\
\text { Sociology in Society } \\
\text { - Value, Norm, and } \\
\text { Socialisation } \\
\text { - Social interaction } \\
\text { - Social Control and } \\
\text { disorder } \\
\text { - Social structure, } \\
\text { conflict and mobility } \\
\text { - Social group in } \\
\text { multicultural society } \\
\text { - Social amendment } \\
\text { and the effect } \\
\text { - Social institution } \\
\text { - Social research } \\
\end{array}$ & $\begin{array}{ll} & \text { Use of Sociology } \\
\text { - } & \text { Mastery of } \\
\text { Sociology } \\
\text { - } & \text { Management of } \\
\text { Subject Materials } \\
\text { and Teaching } \\
\text { Method }\end{array}$ \\
\hline
\end{tabular}

In this study, the avarage score between validity and reliability indicates the quality of teachers' objective tests. The validity score is obtained from the criteria that developed by the Directorate General of Primary and Secondary Education about guidelines of writing and assessment, namely: (1) test items contain subjects based on the curriculum; (2) test items follow specific learning objectives; (3) test items use communicative language; (4) test items based on expected problems; and (5) test items represent for each subject (Directorate General of Primary and Secondary Education, 1995). Content validity is based on these criteria, whereas the empirical validity is taken from the students' score when they do the test. Reliability scores are obtained from calculations using the Kuder-Richardson formula (KR-20) based on available data on each respondent. In order to make the two scores in the same position before being combined, the two scores are converted through the Z-Score and T-Score.

\section{FINDINGS}

Description of the data presented in this section includes the data description and five hypotheses of study.

\section{Description of Teacher's Quality Objective Test}

The data obtained in the field was processed statistically into a list of frequency distributions, the number of classes was determined according to rules 5-15; five classes are determined with a maximum score of 67 and a minimum score of 23 , so the score range is 44 . Data grouping can be seen in the frequency distribution table as follows. 
Table 2

Frequency Distribution of Variables in Quality of Teacher-Made Objective Tests

\begin{tabular}{lllllll}
\hline \multirow{2}{*}{ No. } & Class & Boundary & \multicolumn{4}{l}{ Frequency } \\
\cline { 3 - 7 } & Interval & Bottom & Top & $\mathrm{f}_{\mathrm{a}}$ & $\mathrm{f}_{\text {cum }}$ & $\mathrm{f}_{\mathrm{r}}(\%)$ \\
\hline 1. & $23-31$ & 22,5 & 31,5 & 10 & 10 & 15.38 \\
\hline 2. & $32-40$ & 31,5 & 40,5 & 12 & 22 & 18.46 \\
\hline 3. & $41-49$ & 40,5 & 49,5 & 11 & 33 & 16.92 \\
\hline 4. & $50-58$ & 49,5 & 58,5 & 18 & 51 & 27.69 \\
\hline 5. & $59-67$ & 58,5 & 67,5 & 14 & 65 & 21.54 \\
\hline
\end{tabular}

\section{Description of Test Construction Knowledge}

The participants answered 41 questions which has been validated. The data obtained in the field was processed statistically into a list of frequency distributions, the number of classes was determined according to rules 5-15. Six classes are determined with a maximum score of 39 and a minimum score of 23 with a score range of 16 . Data groupings can be seen in the frequency distribution table as follows.

Table 3

Frequency Distribution of Test Construction Knowledge Score

\begin{tabular}{lllllll}
\hline \multirow{2}{*}{ No. } & Class & Boundary & \multicolumn{4}{c}{ Frequency } \\
\cline { 2 - 7 } & Interval & Bottom & Top & $\mathrm{f}_{\mathrm{a}}$ & $\mathrm{f}_{\text {cum }}$ & $\mathrm{f}_{\mathrm{r}}(\%)$ \\
\hline 1. & $23-25$ & 22,5 & 25,5 & 4 & 4 & 6.15 \\
\hline 2. & $26-28$ & 25,5 & 28,5 & 8 & 12 & 12.31 \\
\hline 3. & $29-31$ & 28,5 & 31,5 & 25 & 37 & 38.46 \\
\hline 4. & $32-34$ & 31,5 & 34,5 & 11 & 48 & 16.92 \\
\hline 5. & $35-37$ & 34,5 & 37,5 & 11 & 59 & 16.92 \\
\hline 6. & $38-40$ & 37,5 & 40,5 & 6 & 65 & 9.23 \\
\hline
\end{tabular}

\section{Description of Teaching Material Mastery}

The participants answered 47 questions in which has been validated. The data obtained in the field was processed statistically into a list of frequency distributions with the number of classes determined according to rules 5-15 where six classes were determined with a maximum score of 49 and a minimum score of 20 and a score range of 29. Data groupings can be seen in the frequency distribution table as follows.

Table 4

Frequency Distribution of Learning Material Mastery Score

\begin{tabular}{lllllll}
\hline No. & $\begin{array}{l}\text { Class } \\
\text { Interval }\end{array}$ & $\begin{array}{l}\text { Boundary } \\
\text { Bottom }\end{array}$ & Top & $\begin{array}{l}\text { Frequency } \\
\mathrm{f}_{\mathrm{a}}\end{array}$ & $\mathrm{f}_{\text {cum }}$ & $\mathrm{f}_{\mathrm{r}}(\%)$ \\
\hline 1. & $20-24$ & 19,5 & 24,5 & 3 & 3 & 4.62 \\
\hline 2. & $25-29$ & 24,5 & 29,5 & 8 & 11 & 12.31 \\
\hline 3. & $30-34$ & 29,5 & 34,5 & 13 & 24 & 20.00 \\
\hline 4. & $35-39$ & 34,5 & 39,5 & 18 & 42 & 27.69 \\
\hline 5. & $40-44$ & 39,5 & 44,5 & 9 & 51 & 13.85 \\
\hline 6. & $45-49$ & 44,5 & 49,5 & 14 & 65 & 21.54 \\
\hline
\end{tabular}




\section{Description of Attitude on Sociology Lessons}

The participants answered 41 questions in which has been validated. The data obtained in the field was processed statistically into the frequency distributions with the number of classes determined according to rules 5-15 where seven classes were determined with a maximum score of 46 and a minimum score of 23 and score range of 23. Data groupings can be seen in the frequency distribution table as follows.

Table 5

Frequency Distribution of Attitude Scores on Sociology Lessons

\begin{tabular}{lllllll}
\hline \multirow{2}{*}{ No. } & Class & Boundary & \multicolumn{4}{l}{ Frequency } \\
\cline { 2 - 7 } & Interval & Bottom & Top & $\mathrm{f}_{\mathrm{a}}$ & $\mathrm{f}_{\text {cum }}$ & $\mathrm{f}_{\mathrm{r}}(\%)$ \\
\hline 1. & $23-26$ & 22,5 & 26,5 & 5 & 5 & 7.69 \\
\hline 2. & $27-30$ & 26,5 & 30,5 & 7 & 12 & 10.77 \\
\hline 3. & $31-34$ & 30,5 & 34,5 & 18 & 30 & 27.69 \\
\hline 4. & $35-38$ & 34,5 & 38,5 & 22 & 52 & 33.85 \\
\hline 5. & $39-42$ & 38,5 & 42,5 & 10 & 62 & 15.38 \\
\hline 6. & $43-46$ & 42,5 & 46,5 & 3 & 65 & 4.62 \\
\hline
\end{tabular}

On the basis of the results of the hypothesis testing conducted. Overall there are five hypotheses tested in this study and it has been proven that the five hypotheses show a linear relationship and significant influence, named $\mathrm{Y}$ on $\mathrm{X} 1, \mathrm{Y}$ on $\mathrm{X} 2$, $\mathrm{Y}$ on $\mathrm{X} 3, \mathrm{X} 3$ on $\mathrm{X} 1$ and $\mathrm{X} 3$ on $\mathrm{X} 2$.

Direct Influence of Knowledge of Test Construction Directly on the Quality of Teacher-Made Objective Tests

The hypothesis tested is:

H0: $\beta 41 \leq 0$

H1: $\beta 41>0$

Based on the results of data analysis, obtained path coefficient X1 to $\mathrm{Y}(\beta 41)=0.301$ with the value of $t$ count $=3.756>2,000(\mathrm{t}$ table) at the significance level $\alpha=0.05$ and the $\mathrm{P}$-value coefficient is smaller than $0.05(0.000<0,05)$ which means $\mathrm{H} 0$ is rejected and $\mathrm{H} 1$ is accepted. This finding reveals that the path coefficient is very significant which means that the Test Construction Knowledge (X1) has a positive effect directly on the Quality of the Teacher-Made Objective Test (Y).

Table 6

Influence Path Coefficient X1 on Y

\begin{tabular}{|c|c|c|c|c|c|c|}
\hline \multirow{2}{*}{$\begin{array}{c}\text { Direct } \\
\text { influence }\end{array}$} & \multirow{2}{*}{$\begin{array}{c}\text { Path } \\
\text { coefficient }\end{array}$} & \multirow[b]{2}{*}{$\mathrm{t}_{\text {count }}$} & \multicolumn{2}{|c|}{$\mathrm{t}_{\text {table }}$} & \multirow{2}{*}{ Sig. } & \multirow{3}{*}{$\begin{array}{l}\alpha \quad= \\
0,05\end{array}$} \\
\hline & & & $\alpha=0,05$ & $\alpha=0,01$ & & \\
\hline $\mathrm{X}_{1}$ toward $\mathrm{X}_{4}$ & 0,301 & $3,756^{\text {*** }}$ & 2,000 & 2,660 & $0,000 * *$ & \\
\hline
\end{tabular}

Direct effect the path coefficient $t$ counts t table Sig. $\alpha=0.05$

Direct Influence of Persuasive Communication Directly on the Quality of Service)

The hypothesis tested is:

H0: $\beta 42 \leq 0$

H1: $\beta 42>0$ 
Based on the results of data analysis, obtained the path coefficient X2 to Y $(\beta 42)=$ 0.539 with the price of $\mathrm{t}$ count $=6.318>2,000(\mathrm{t}$ table) at the significance level $\alpha=0.05$ and the P-value coefficient is smaller than $0.05(0.000<0$, 05) which means $\mathrm{H} 0$ is rejected and $\mathrm{H} 1$ is accepted. This means that the path coefficient $\mathrm{X} 2$ on $\mathrm{Y}$ is very significant; there is a positive influence of the Teaching Material Mastery directly towards the Quality of Teacher-Made Objective Tests.

Table 7

Influence Path Coefficient X2 on Y

\begin{tabular}{|c|c|c|c|c|c|c|}
\hline \multirow{2}{*}{ Direct influence } & \multirow{2}{*}{$\begin{array}{l}\text { Path } \\
\text { coefficient }\end{array}$} & \multirow{2}{*}{$\mathrm{t}_{\text {count }}$} & \multicolumn{2}{|l|}{$\mathrm{t}_{\text {table }}$} & \multirow{2}{*}{ Sig. } & \multirow{3}{*}{$\alpha=0,05$} \\
\hline & & & $\alpha=0,05$ & $\alpha=0,01$ & & \\
\hline $\mathrm{X}_{2}$ toward $\mathrm{X}_{4}$ & 0,539 & $6,318 * *$ & 2,000 & 2,660 & $0,000 * *$ & \\
\hline
\end{tabular}

** significant path coefficient $(6,318>2,000$ at $\alpha=0,05)$

** $\mathrm{P}$-value coefficient is smaller than $0.05(0,000<0,05)$

Direct Influence of Attitudes on Sociology Lessons influence on the Quality of Teacher-Made Objective Tests

The hypothesis tested is:

H0: $\beta 43 \leq 0$

H1: $\beta 43>0$

Based on the results of data analysis, obtained the path coefficient X3 to Y ( $\beta 43)$ of 0.209 with the price of $t$ count $=2.354>2,000$ at a significance level of $\alpha=0.05$ and the $\mathrm{P}$-value coefficient is less than $0.05(0.022<0.05)$ which means $\mathrm{H} 0$ is rejected and $\mathrm{H} 1$ is accepted. This shows that the path coefficient $\mathrm{X} 3$ on $\mathrm{Y}$ is very significant. This finding suggests that the attitude of Sociology Lessons affects positively the Quality of TeacherMade Objective Tests. This means that any positive changes that occur in the Attitude of Sociology Lessons directly affect the Quality of Artificial Objective Tests.

Table 8

Influence Path Coefficient $\mathrm{X}_{3}$ on $\mathrm{Y}$

\begin{tabular}{llllll}
\hline \multirow{2}{*}{ Direct influence } & $\begin{array}{l}\text { Path } \\
\text { coefficient }\end{array}$ & $\mathrm{t}_{\text {count }}$ & \multicolumn{2}{l}{ S table } & \\
\cline { 3 - 4 } $\mathrm{X}_{3}$ toward $\mathrm{X}_{4}$ & 0,209 & $2,354 * 0,05$ & $\alpha=0,01$ & Sig.
\end{tabular}$\quad \alpha=0,05$

** significant path coefficients $(2,354>2,000$ at $\alpha=0,05)$

** $\mathrm{P}$-value coefficient is smaller than $0.05(0.022<0.05)$

Direct Influence of Knowledge of Test Construction on the attitude of Sociology Lessons)

The hypothesis tested is:

$\mathrm{H} 0: \beta 31 \leq 0$

$\mathrm{H} 1: \beta 31>0$ 
Based on the results of data analysis, obtained pathway coefficient X1 to X3 ( $\beta 31)$ of 0.266 with the price of $t$ count $=2.428>2,000$ at a significance level of $\alpha=0.05$ and the $\mathrm{P}$-value coefficient is smaller than $0.05(0.018<0.05)$ which means $\mathrm{H} 0$ is rejected and $\mathrm{H} 1$ is accepted. This means that the path coefficient $\mathrm{X} 1$ to $\mathrm{X} 3$ is very significant. Interpretation of this finding suggests that the Construction Knowledge Test has a positive effect directly on the attitude of Sociology Lessons.

Table 9

Effect Path Coefficient $\mathrm{X}_{1}$ on $\mathrm{X}_{2}$

\begin{tabular}{llllll}
\hline \multirow{2}{*}{ Direct influence } & $\begin{array}{l}\text { Path } \\
\text { coefficient }\end{array}$ & $\mathrm{t}_{\text {count }}$ & $\mathrm{t}_{\text {table }}$ & & \multirow{2}{*}{ Sig. } \\
\cline { 2 - 5 } $\mathrm{X}_{1}$ toward $\mathrm{X}_{2}$ & 0,423 & $2,428 * *$ & 2,000 & 2,660 & $0,018 * *$ \\
\end{tabular}

** coefficient is very significant $(2,428>2,000$ at $\alpha=0,05)$

** $\mathrm{P}$-value coefficient is smaller than $0.05(0.018<0.05$

\section{Direct Influence of X2 on X3 (Mastery of Teaching Materials affects directly} towards the attitude of Sociology Lessons)

The hypothesis tested is:

H0: $\beta 32 \leq 0$

$\mathrm{H} 1: \beta 32>0$

Based on the results of data analysis, obtained path coefficient X2 to X3 ( $\beta 32)$ of 0.423 with the price of $\mathrm{t}$ count $=3.867>2,000$ ( $\mathrm{t}$ table) at the significance level $\alpha=0.05$ and the P-value coefficient is smaller than $0.05(0.000<0,05)$ which means $\mathrm{H} 0$ is rejected and $\mathrm{H} 1$ is accepted. This shows that the $\mathrm{X} 2$ path coefficient on X3 is very significant. In other words, there is a positive influence of the Mastery of Teaching Materials directly towards the Attitudes of Sociology Lessons. Therefore, the Mastery of Teaching Materials has an effect directly on the attitude of Sociological Lessons can be accepted.

Table 10

Effect Path Coefficient $\mathrm{X}_{3}$ on $\mathrm{X}_{2}$

\begin{tabular}{|c|c|c|c|c|c|c|}
\hline \multirow{2}{*}{ Direct influence } & \multirow{2}{*}{$\begin{array}{l}\text { Path } \\
\text { coefficient }\end{array}$} & \multirow{2}{*}{$\mathrm{t}_{\text {count }}$} & \multicolumn{2}{|l|}{$\mathrm{t}_{\text {table }}$} & \multirow{2}{*}{ Sig. } & \multirow{3}{*}{$\alpha=0,05$} \\
\hline & & & $\alpha=0,05$ & $\alpha=0,01$ & & \\
\hline$X_{3}$ toward $X_{2}$ & 0,243 & $3,867 * *$ & 2,000 & 2,660 & $0,000 * *$ & \\
\hline
\end{tabular}

** significant path coefficient $(3,867>2,000$ at $\alpha=0,05)$

** P-value coefficient is smaller than $0.05(0,000<0,05)$.

\section{DISCUSSION}

The discussion of each hypothesis is described below.

\section{Construction Knowledge Tests have a Direct Positive Effect on The Quality of Teacher's Objective Tests}

Based on the results of data analysis, obtained path coefficient $\mathrm{X} 1$ to $\mathrm{Y}(\beta 41)=0.301$ with the price of $\mathrm{t}$ count $=3.756>2,000$ ( $\mathrm{t}$ table) at the significance level $\alpha=0.05$ and the $\mathrm{P}$-value coefficient is 0.000 which is smaller than $0.05(0,000<0,05)$ means that $\mathrm{H} 0$ 
$\mathrm{X}$ is rejected. It also means that the research hypothesis is accepted. The analysis reveals that the path coefficient is significant. It means that Test Construction Knowledge (X1) has positive effect on the Quality of Teacher-Made Objective Tests (Y), or any positive changes that occur in the Test Construction Knowledge will lead to a positive change in the quality of the test. Thus, the quality of the objective test made by the teacher is influenced by the Test Construction Knowledge. This is relevant with Agu et al.'s (2013) findings which state that the quality of tests correlates with the teacher's ability to provide information needed to improve student performance. The ability to design test will lead to the accuracy in measuring learning outcomes and result in students' misunderstanding, and the effectiveness of the learning process. This means that cognitive ability, as an initial ability, is influenced by the character of a teacher's professional attitude, one of which is knowing how assessment can improve student learning achievement. Fitt et al. (1999) believe that it is important for teachers to always improve their knowledge about testing and that any teacher who does not have sufficient knowledge about testing cannot construct tests properly. Griswold (1990) suggests that teachers who have high knowledge on test will produce relevant and reliable tests.

\section{Mastery of Teaching Materials has a Direct Positive Effect on The Quality of Objective Tests Made by Teachers}

Results of data analysis obtained the path coefficient X2 to Y $(\beta 42)=0.539$ with the price of $t$ count $=6.318>2,000$ ( $\mathrm{t}$ table) at the significance level $\alpha=0.05$ and the Pvalue coefficient is smaller than $0.05(0.000<0,05)$ which means that $\mathrm{H} 0$ is rejected or the research hypothesis is accepted. This means that the path coefficient $\mathrm{X} 2$ to $\mathrm{Y}$ is significant. In other words, there is a positive influence on the mastery of teaching materials towards the quality of objective tests made by the teacher. Any positive changes that occur in the mastery of teaching materials have an effect on improving the quality of objective tests made by the teacher. Thus, it can be concluded that the quality of the objective test made by the teacher is directly influenced by the mastery of teaching materials. In other words, the ability of the teacher in mastering the material which includes the use of language, the scope of the organization's content and test's knowledge applies directly to the measurement of a teacher's test construction skills. Obot (2012) supports this finding that the level of teacher's knowledge of subject influences the process of achieving the learning objectives. Rice (2003) also emphasizes that teachers must have sufficient knowledge in their teaching fields as those who do not have sufficient knowledge of their subject matter will not be effective in achieving student learning. In conclusion, improving the quality of teacher-made tests can be carried out and pursued by increasing mastery of subject matter by the teacher. The higher the teacher's mastery of the learning material, the higher the quality of the tests made or, if the mastery of the teacher's material is low, the quality of the tests made decreases.

The Attitude towards Sociology Lessons has a Direct Positive Effect on The Quality of The Objective Test Made by The Teacher

The results of data analysis obtained a path coefficient X3 to Y ( $\beta 43)$ of 0.209 with the price of $t$ count $=2.354>2,000$ at a significance level of $\alpha=0.05$ and the P-value 
coefficient is smaller than $0.05(0.022<0.05)$ which means $\mathrm{H} 0$ is rejected. The analysis shows that the path coefficient $\mathrm{X} 3$ to $\mathrm{Y}$ is significant and that a teacher's attitude towards sociology lessons has a positive effect on the quality of objective tests made by the teacher. Any positive changes that occur in attitudes to Sociology lessons have an effect on improving the quality of objective tests made by teachers. Therefore, the hypothesis which states that the attitude towards Sociology lessons directly influences the quality of the objective test made by the teacher can be accepted. Thus, it can be concluded that the objective test quality made by teachers is directly influenced by their attitude towards Sociology lessons. Kpolovie (2014) supports these findings that attitude shows a significant correlation to the quality of a lesson meaning that a positive attitude towards a lesson will show a significant correlation with the learning activities. Interest in participating the lessons will increase and activate students' involvement. Shaukat (2014) considers that a teacher's attitude towards effectiveness does not change from the beginning to the end of a teacher preparation program. Teachers with high qualifications are assumed to perform high-level cognitive tasks compared to teachers who have low professional qualifications. A teacher with a higher level of education tends to perform better than a teacher with a lower level of education (Kurgat, 2014), concluding that if a teacher has a positive attitude towards their subject it will affect the quality of their tests and, in turn, will produce good results. Ngeche (2017) also shows that attitudes will significantly affect teacher performance and suggests that the teacher as a facilitator in the teaching and learning process must build cognitive, affective and behavioral competencies for students. It can be concluded that the more positive a teacher's attitude is towards sociology lessons, the higher the quality of tests made or, conversely, a negative attitude towards sociology lessons, will reduce the quality of the tests. A positive attitude toward sociology is partly due to an assumption by the teacher's development and preparation of a test which is an inherent part of a teacher's duties and responsibilities to students. Teachers are not only tasked with delivering subject matter but they have a responsibility to students which should be professional.

\section{Knowledge of Test Construction Has A Direct Positive Effect on Attitude towards Sociology Lessons}

Based on the results of data analysis, obtained pathway coefficient X1 to X3 ( $\beta 31$ ) of 0.266 with the price of $t$ count $=2.428>2,000$ at a significance level of $\alpha=0.05$ and the $\mathrm{P}$-value coefficient is smaller than $0.05(0.018<0.05)$ which means $\mathrm{H} 0$ is rejected and $\mathrm{H} 1$ is accepted. This means that the path coefficient $\mathrm{X} 1$ to $\mathrm{X} 3$ is very significant. The results of this analysis suggest that test construction knowledge has a direct positive effect on attitude towards sociology lessons. Any positive changes that occur in the knowledge of test construction have a positive effect on influencing attitudes towards sociology lessons. Therefore, the hypothesis which states that the knowledge of test construction has an effect on the attitude of sociology lessons can be accepted. Thus, it can be concluded, that the attitude towards sociology lessons is directly influenced by the construction knowledge of the test. Teachers who have high knowledge of test construction, accompanied by a positive attitude towards sociology lessons, always strive to get the best results and this affects the quality of their work. Teachers who can construct the tests effectively also have a positive attitude towards Sociology lessons 
that will complete all tasks well include developing test items. These findings are supported by Ozogul and Sullivan (2009) who indicate that students' attitudes that are more positive towards test knowledge will significantly improve learning outcomes. Gullickson (2015) also said that teachers who viewed themselves as having had enough knowledge about testing, even though most teachers had limited knowledge about the construction of tests would have an effect on attitudes towards learning. In conclusion, teachers who understand test construction and have a positive attitude towards the lesson will develop quality test items for teacher-made tests.

\section{Mastery of Teaching Materials Has A Direct Positive Effect on Attitudes to Sociology}

Based on the results of data analysis, obtained path coefficient X2 to X3 ( $\beta 32$ ) of 0.423 with the price of $\mathrm{t}$ count $=3.867>2,000(\mathrm{t}$ table) at the significance level $\alpha=0.05$ and the $\mathrm{P}$-value coefficient is smaller than $0.05(0.000<0,05)$ which means $\mathrm{H} 0$ is rejected and $\mathrm{H} 1$ is accepted. This shows that the path coefficient of $\mathrm{X} 2$ is significant. In other words, there is a positive direct influence of the mastery of teaching materials on attitudes toward sociology. This means that any positive changes that occur in the mastery of teaching materials have a positive effect on increasing attitudes towards sociology. Therefore, the hypothesis which states that the mastery of teaching materials has a direct positive effect on sociology lessons can be accepted. It can be concluded that a teacher who mastery the teaching material and have positive attitude towards Sociology learning, will be successful in developing high-quality tests, whereas teachers who have poor mastery of teaching materials and negative views about sociology learning will have difficulty in developing quality test. Carter (1984) supports this proposition and states that, because many teachers cannot recognize certain skills being tested, teacher training programs must focus on increasing the teacher's knowledge of testing. Programs that focus on increasing the development of knowledge about mastery of subject is needed to support teachers. In order to improve teachers' mastery of subject, professional development programs need to consider using techniques and strategies to develop a deep understanding of mastery the subject matter (Driel \& Berry, 2012). Ball et al. (2008) believe that the mastery of teaching materials is important. A teacher must know the subject that they teach. In conclusion, teachers who have a high mastery of learning material and a positive attitude toward sociology lessons will develop quality test items. Therefore, the higher the mastery of the material accompanied by a teacher's positive attitude towards the subject, the higher the quality of objective tests created by the teacher which can be expected to have a direct influence on the mastery of the material and attitudes towards Sociology learning.

\section{CONCLUSION}

Based on the results of thought, findings and discussion, as stated in the previous section, that all five hypotheses are accepted, and the fifth hypothesis can be concluded as follows: First, test construction knowledge has a positive influence directly on the quality of a teacher's objective test. This shows that if a teacher's test construction knowledge is improved, the quality of teacher's objective tests will also improve. Second, mastery of Sociology teaching materials has a positive influence directly on the quality of teacher's objective tests. thus, the mastery of Sociology teaching materials 
determines the quality of teacher's objective tests. It means that if the mastery of Sociology teaching materials is improved then the quality of teacher-made objective test will also increase. Third, attitudes towards Sociology lessons have a positive influence directly on the quality of teacher's objective tests. Thus, attitudes towards Sociology lessons determine the quality of teacher's objective tests. Fourth, knowledge of test construction has a positive influence directly on the attitude towards Sociology lessons. this shows that if the teacher's construction test knowledge is improved, then the attitude of Sociology lessons will also improve. Fifth, mastery of Sociology teaching materials has a positive influence directly on the attitude towards sociology. thus, the mastery of sociology teaching materials also determines attitudes towards Sociology. Finally, this study show the importance of teachers competences in constructing test and attitude toward subject to develop good test quality in the learning assessment.

\section{REFERENCES}

Agu, N. N., C. Ony Ekuba, C. O., \& Anyihie, A. C. (2013). Measuring teacher's competency in constructing classroom based test in Nigerian secondary school: Need for a test construction skill inventory. Educational Research and Review, 8(8), 431-439.

Ball, D. L., Thames, M. H., \& Phelps. G. (2008). Content knowledge for teaching: What makes it special? Journal of Teacher Education, 59(5), 389-407.

Carter, K. (1984). Do teachers understand principles for writing tests? Journal of Teacher Education, 35(6), 57-60

Darling-Hammond, L. (2002). Teacher quality and student achievement: A review of state policy evidence. Educational policy analysis archives, 8(1), 1-44.

Driel, J. H. V., \& Berry, A. (2012). Teacher professional development focusing on pedagogical content knowledge. Educational Researcher, 41(1), 26-28.

Directorate General of Primary and Secondary Education. (1995). Guidelines of Writing and Assessment. Jakarta: Department of National Education.

Ell. F., Hill, M., \& Grudnoff. L. (2012). Finding out more about teacher candidates' prior knowledge implications for teacher educators. Asia Pacific Journal of Teacher Education, 40(1), 55-56.

Fitt. D., Rafferty. K., Presner, M. T., \& Heve, R. (1999). Improving the quality of teacher classroom test educational. Academic Journal Article Education, 119(4), 643648.

Gichuhi., C. (2014). Teachers' competence in tests construction within Blooms taxonomy for effective learning assessment: A case study of Kikuyu District, Kiambu County. Master Thesis. Kenya: University Of Nairobi.

Griswold, P. A. (1990). Assessment relevance and reliability to improve the quality of teacher made tests. NASSP Bulletin, 74(523), 1-24

Gullickson, A. R. (2015). Teacher perspectives of their instructional use of tests. The Journal of Educational Research, 77(4), 244-248. 
Inyiagu, E. E. (2014). Challenges facing technical and vocational education in Nigeria. Journal of Educational Policy and Entrepreneurial Research, 1(1), 40-45.

Khalid, A., Azeem, M., \& Bashir, M. (2011). English as Second Language: Alignment Perspective as Quality Improvement in Pakistan. International Journal of Humanities and Social Science. 1 (20), 264-269.

Kpolovie, P. J. (2014). Academic achievement prediction: The role of interest in learning and attitude towards school. International Journal of Humanities Social Sciences and Education, 1(11), 73-100.

Kurgat, S. J. (2014). The effects of teacher characteristics and attitudes on student achievement in kcse economics examination. International Journal of Education Learning and Development, 2(5), 33-43.

McMillan, (2000). Essential assessment concepts for teachers and administrators. Thousand Oaks, CA Corwin publishing company. Amazon.com

Ministry of Education. (2013). The national education system, No. 20/2013, article 1. Jakarta: Ministry of Education and Culture.

Minor, E. C., \& Desimone, L. (2016). Insights on how to shape teacher learning policy: The role of teacher content knowledge in explaining differential effects of professional development. Education Policy Analysis Archives, 24(61), 1-29

Ngeche, T. N. M (2017). Student and teacher attitude as correlates of performance in mathematics in Cameroon secondary schools, International Journal of Humanities Social Sciences and Education, 4(12), 1-10.

Nilsson, P., \& Driel, J. V. (2011). How will we understand what we teach? Primary student teachers' perceptions of their development of knowledge and attitudes towards physics. Research in Science Education, 41(4), 541-560. DOI 10.1007/s11165-0109179-0.

Obot, I. M. (2012). Influence of teacher's competence in subject matter on students' interest in the learning of social studies education in Akwalbom State, Nigeria. International Journal of Teaching and Education, 2(3), 127- 154

Ololube, N. P. (2008). Evaluation competencies of professional and nonprofessional teachers in Nigeria. Studies in Educational Evaluation, 34(1), 44-51.

Osadebe, P. U. (2015). Construction of valid and reliable test for assessment of students. Journal of Education and Practice, 6(1), 51-56.

Osadebe, P. U., \& Kpolovie, P. J. (2008). Validation of educational research and evaluation in Nigeria. Journal of Vocational Science and Educational Development. 8(1), 103-108.

Ozogul, G., \& Sullivan., H. (2009). Student performance and attitudes under formative evaluation by teacher, self and peer evaluators. Education Technology Research Development, 57(3), 393-410 
Rahmawati, Y. (2013). Revealing and reconceptualising teaching identity through the landscapes of culture, religion, transformative learning, and sustainability education: A transformation journey of a science educator. Doctoral Thesis. Perth: Curtin University.

Rambo, K. E., \& Coach, D. B. M. (2012). Teacher attitudes toward subject-specific acceleration: Instrument development and validation. Journal for the Education of the Gifted, 35(2), 129-152.

Tritiyatma, H., Rahmawati,Y., \& Ridwan, A. (2017). Developing 21st century skills in chemistry classrooms: Opportunities and challenges of STEAM integration. AIP Conference Proceedings 1868, 030008 (2017); DOI: 10.1063/1.4995107.

Rice, J. K. (2003). Teacher quality: Understanding the effectiveness of teacher attributes. Washington, DC: Economic Policy Institute.

Rohaan, E. J., Taconis, R., \& Jochems, W. M. G. (2012). Analyzing teacher knowledge for technology education in primary schools. International Journal Technology Design Education, 22(3), 271-280.

Shaukat, S. (2014). Attitude of student teachers toward assessment, peers, subject matter, and teacher educator effectiveness. The Macrotheme Review, 3(2), 147-158.

UNESCO (2001). Revised recommendation concerning technical and vocational education. Retrieved from https://en.unesco.org/themes/skills-work-and-life/tvetrecommendation on 27 January 2019.

Wahyudin, D. (2018). Peace education curriculum in the context of Education Sustainable Development (ESD). Journal of Sustainable Development Education and Research, 2(1), 21-32. 